\title{
Ichthyometry and electrical bioimpedance analysis to estimate the body composition of tambatinga
}

\author{
Francisco Teixeira ANDRADE¹, Márvio Lobão Teixeira de ABREU², João Batista LOPES ${ }^{3}$, Agustinho Valente \\ de FIGUEIREDO ${ }^{3}$, Maria de Nazaré Bona Alencar ARARIPE 3 , Antônio Hosmylton Carvalho FERREIRA ${ }^{4}$ \\ 1 Universidade Federal do Piauí, Departamento de Biofísica e Fisiologia, CEP: 64049-550. Teresina, Piauí, Brazil. frantean@gmail.com \\ ${ }^{2}$ Universidade Federal de Lavras, Departamento de Zootecnia, CEP: 37200-000. Lavras, Minas Gerais, Brazil. \\ 3 Universidade Federal do Piauí, Departamento de Zootecnia, CEP 64049-550. Teresina, Piauí, Brazil. lopesjb@uol.com.br, agustinhov@yahoo.com.br, hararipe@ufpi.edu.br. \\ ${ }^{4}$ Universidade Estadual do Piauí, Campus de Corrente, CEP 64002-150. Corrente, Piauí, Brasil. hosmylton@hotmail.com \\ * Corresponding Author: marvioabreu@uol.com.br
}

\begin{abstract}
Body composition analysis is relevant to characterize the nutritional requirements and finishing phase of fish. The aim of this study was to investigate the relationship between ichthyometric (weight, total and standard length, density and yields), bromatological (fat, protein, ash and water content) and bioelectrical-impedance-analysis (BIA) (resistance, reactance, phase angle and composition indexes) variables in the hybrid tambatinga (Colossoma macropomum $\times$ Piaractus brachypomus). In a non-fertilized vivarium, 520 juveniles were housed and fed commercial rations. Then, 136 days after hatching (DAH), 15 fish with an average weight of $37.69 \mathrm{~g}$ and average total length of $12.96 \mathrm{~cm}$ were randomly chosen, anesthetized (eugenol) and subjected to the first of fourteen fortnightly assessments (BIA and biometry). After euthanasia, the following parts were weighed: whole carcass with the head, fillet, and skin (WC); fillet with skin (FS); and the remainder of the carcass with the head $(\mathrm{CH})$. Together, FS and $\mathrm{CH}$ were ground and homogenized for the bromatological analyses. Estimates of the body composition and yields of tambatinga, with models including ichthyometric and BIA variables, showed correlation coefficients ranging from 0.81 (for the FS yield) to 1,00 (for the total ash). Similarly, models that included only BIA variables had correlation coefficients ranging from 0.81 (FS and $\mathrm{CH}$ yields) to 0.98 (for the total ash). Therefore, in tambatinga, the BIA technique allows the estimation of the yield of the fillet with skin and the body composition (water content, fat, ash, and protein). The best models combine ichthyometric and BIA variables.
\end{abstract}

KEYWORDS: bromatology, fish, non-lethal assessment, reactance, resistance.

\section{Ictiometria e bioimpedância elétrica para estimativa da composição corporal do tambatinga}

RESUMO

Analisar composição corporal é relevante para caracterizar necessidades nutricionais e fase de terminação de peixes. Objetivou-se estudar a relação entre variáveis ictiométricas (peso, comprimentos total e padrão, densidade e rendimentos), bromatológicas (gordura, proteína, cinza e umidade) e aquelas da análise por bioimpedância ou BIA (resistência, reatância, ângulo de fase e índices de composição), no híbrido tambatinga (Colossoma macropomum x Piaractus brachypomus). Em um viveiro não fertilizado, 520 juvenis foram cultivados com ração comercial. Com idade de 136 dias após a eclosão dos ovos, 37,69 g de peso, 12,96 $\mathrm{cm}$ de comprimento total, 15 peixes, colhidos ao acaso, foram anestesiados (eugenol) e submetidos à primeira de quatorze avaliaçóes quinzenais (BIA e biometria). Após eutanásia foram dissecados e pesados: carcaça inteira com cabeça, filé e pele (CICFP), filé com pele (FCP) e resto da carcaça com cabeça (CCC). Juntos, FCP e CCC foram moídos e homogeneizados para análise bromatológica. Estimativas da composiçáo corporal e de rendimentos do tambatinga, com modelos incluindo variáveis ictiométricas e da BIA, apresentaram coeficientes de correlação entre 0,81 (para o rendimento do FCP) e 1,00 (para cinzas totais). Analogamente, modelos com a inclusão apenas de variáveis da BIA mostram coeficientes de correlação entre 0,81 (rendimento do FCP e do CCC) e 0,98 (para cinzas totais). Portanto, no tambatinga, a técnica da BIA possibilita a estimativa do rendimento de filé com pele e composição corporal (umidade, gordura, cinza e proteína). Os melhores modelos agregam variáveis ictiométricas e da BIA.

PALAVRAS-CHAVE: bromatologia, avaliação não letal, peixe, reatância, resistência. 


\section{INTRODUCTION}

The study of the performance and body composition of fish, particularly focused on the deposition of lean tissue, has stood out in scientific research, especially due to its relevance in determining and optimizing the nutritional requirements of fish. Many methods provide regression equations that relate the management of nutrients to performance and body composition variables (Bomfim et al. 2008; Teixeira et al. 2006). Additionally, the carcass and fillet yields are measured, and these measurements make it possible to characterize the final product; evaluate the potential for industrialization; determine the ideal slaughter weight; and also mathematically predict these values (Freato et al. 2005).

Indirect methods for analyzing the body composition include densitometry, dilution, conductance and bioelectrical impedance, X-ray absorptiometry, computerized tomography, magnetic resonance imaging, and others (Braulio et al. 2010; Ellis 2000; Pinto et al. 2005). All these techniques are useful for estimating the body composition of animal species (Duncan et al. 2007) and enable the study of the growth curve for lean tissue and the yields. Bioelectrical impedance analysis (BIA), widely used to estimate the body composition of humans and other animals (Kyle et al. 2004a and b; Valliant and Tidwell, 2007), is performed with a four-terminal BIA analyzer that accurately measures the electrical resistance $(R)$ and the electrical reactance $(\mathrm{Xc})$, allowing the calculation of electrical impedance $(Z)$ and other BIA parameters, e.g., the phase angle (PA) and the composition indexes (CI).

Estimating fish body composition using BIA is justified because it is a safe, fast, easy-to-perform, simple and inexpensive technique that evaluates entire body variables and enables the performance of fieldwork (Ellis, 2001) and, most important, is not lethal (Bourdages 2011). The nonlethal nature of this technique is especially important when analyzing specimens that, for some reason, cannot be sacrificed, such as endangered species or animals used in longitudinal studies (Willis and Hobday 2008). Furthermore, the total cost of body composition analysis using BIA may be 20 to 41 times lower than assessment based on chemical analysis if the BIA is performed in-house vs. at an external laboratory for the chemical analysis (Duncan, 2008).

Tambatinga is a hybrid species whose parents, tambaqui (Colossoma macropomum ㅇ) and pirapitinga (Piaractus brachypomus $\left.{ }^{\top}\right)$ ), belong to the order Characiformes, family Characidae and subfamily Serrasalminae and can reach more than $80 \mathrm{~cm}$ in total length and weight $20 \mathrm{~kg}$ or more (Soares et al. 2008). In Brazil, tambatinga production is under significant growth (IBAMA 2008; BRASIL 2010).

The objective of this study was to make the BIA technique feasible as a tool to estimate the body composition and yields of tambatinga at an important stage of the weight and length development of this hybrid.

\section{MATERIALS AND METHODS}

A total of 520 tambatinga juveniles, whose age was measured in days after hatching (DAH), were acquired from a certified fingerling production unit (DNOCS, Piripiri, Piauí, Brazil). These fish were housed in a vivarium (length $40 \mathrm{~m}$; width $30 \mathrm{~m}$; water-level control tank depth $1.5 \mathrm{~m}$ and inclination $2.15^{\circ}$; surface area $1200 \mathrm{~m}^{2}$; estimated capacity or volume 900,000 L; supplied with driven well water without fertilization) whose geographic coordinates are $05^{\circ} 05^{\prime} 21$ " $S$ latitude, $42 \circ 48^{\prime} 07^{\prime}$ W longitude and $72 \mathrm{~m}$ of altitude.

The tambatingas received commercial rations suited for each growth phase (from the juvenile stage to the growth phase, the daily ration supplied decreased from 6.0 to $2.0 \%$ of the biomass) at a daily quantity based on the estimated biomass and the amount of feed leftovrs at the vivarium surface. At $136 \mathrm{DAH}, 15$ fish weighing $37.69 \pm 3.32 \mathrm{~g}$ with an average total length of $12.96 \pm 0.37 \mathrm{~cm}$ were randomly chosen, anesthetized with eugenol (Vidal et al. 2008) and subjected to the first of fourteen fortnightly assessments. Signal electrodes and detectors (Delta 20-5 hypodermic needles) were inserted 1 (one) $\mathrm{cm}$ deep at well-defined spots on the fish (Figure 1) for the measurement of the BIA variables resistance (R) and electrical reactance (Xc), in series. The four-terminal BIA analyzer used (model BIA-101Q, RJL Systems, Clinton Township, MI, USA, http://www.rjlsystems.com) produces a characteristic alternating current of $800 \mu \mathrm{A}$ and $50 \mathrm{kHz}$.

The impedance $(\mathrm{Z})$, phase angle $(\mathrm{PA})$ and composition indexes (CI) were calculated by formulas (1), (2) and (3):

$\mathrm{Z}($ in $\mathrm{Ohm})=\left(\mathrm{R}^{2}+\mathrm{Xc}^{2}\right)^{1 / 2}(1)$

$\mathrm{PA}$ (in degrees) $=\arctan \mathrm{Xc}^{-1} 180^{\circ} \pi^{-1}$ (Foster and Lukaski 1996) (2)

$\mathrm{CI}_{\mathrm{S}}\left(\right.$ in $\left.\mathrm{cm}^{2} \mathrm{Ohm}^{-1}\right)=\mathrm{S}^{2} \mathrm{Xc}^{-1}(3)$

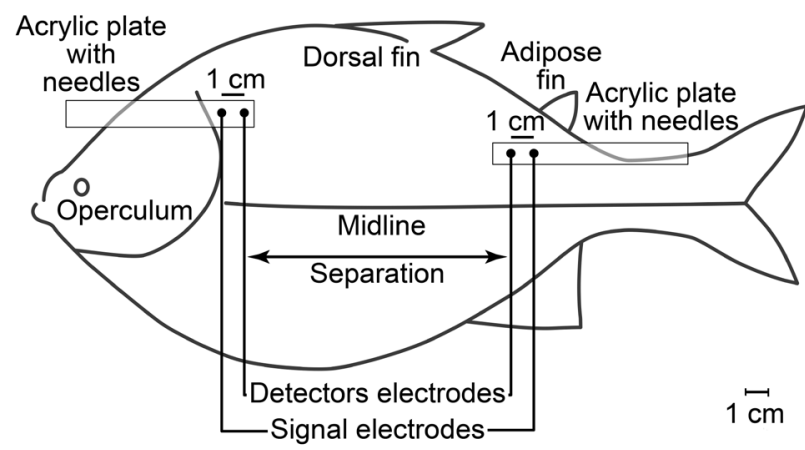

Figure 1 - Insertion points for the needles that connect the electrodes for performing bioelectrical-impedance-analysis in a tambatinga fish. 
where $S$ is the distance or separation between the detector electrodes (Willis and Hobday 2008). The substitution of S with the total length (TL) or the standard length (SL) was tested.

The following ichthyometric data were collected: weight (P), TL, SL and volume (V). The body density (BD = weight volume $^{-1}$ ) and Fulton's condition factor (Fulton's $\mathrm{K}$ or $\mathrm{K}$ in $\mathrm{g}$ $\mathrm{mm}^{-3}=$ weight length ${ }^{-3}$ ) were also calculated.

After euthanasia, descaling and evisceration, the whole carcass with head, fillet and skin (WC); fillet with the skin (FS); and the remainder of the carcass with the head $(\mathrm{CH})$ were weighed. Together, the FS and the $\mathrm{CH}$ were ground three times and homogenized until a substance with sticky consistency was obtained. Part of this homogenized mixture was frozen at $-20^{\circ} \mathrm{C}$ for later bromatological analysis. The water content was determined by drying the homogenized mixture at $105^{\circ} \mathrm{C}$ for 24 hours in a drying oven (Silva and Queiróz 2002). The crude protein content was determined, in triplicate, using the Kjeldahl method (AOAC 1984). The fat was isolated, in duplicate, by petroleum ether extraction using the Ankom Extraction System (model ANKOM XT10 Extractor, ANKOM Technology, NY, USA, http://www. ankom.com/product/ankom-xt10-extractor,-120v.aspx). The amount of ash was measured by incinerating the dry matter at $600{ }^{\circ} \mathrm{C}$ for four hours in a muffle (Silva and Queiróz 2002).

The ichthyometric and BIA data or the BIA data alone were regressed against the data of the approximate analysis to construct models. The GLM procedure in SAS (SAS 2004) was used, and Mallows' Cp statistic was calculated to test the fitting of the number of variables of the models.

This study was approved by the Ethics Committee for Experiments with Animals/Federal University of Piauí (Report number 009/11 of April 26, 2011).

\section{RESULTS}

Only for morphological characterization, fifteen randomly chosen fishes were measured (weight: $837.20 \pm 70.45 \mathrm{~g}$; total length: $34.39 \pm 1.24 \mathrm{~cm}$; height and width at the largest body diameter: $13.65 \pm 0.54 \mathrm{~cm}$ and $4.85 \pm 0.26 \mathrm{~cm}$, respectively), confirming the rounded shape characteristic of tambatinga.

The temperature and relative humidity of the climatecontrolled environment where the measurements were carried out (BIA and ichthyometric) were $24.71{ }^{\circ} \mathrm{C} \pm 1.77{ }^{\circ} \mathrm{C}$ and $56.79 \% \pm 2.97 \%$, respectively, during the study period.

Except for the body density, all ichthyometric variables for the tambatingas showed the expected linear increase ( $P$ $<0.001)$ as the age advanced over the experimental period (Table 1).

During this period, the yield of the whole carcass with the head, fillet, and skin (nWC), presented in Table 2, did not
Table 1 - Colossoma macropomum $\times$ Piaractus brachypomus. Ichthyometric data and Fulton's $\mathrm{K}$ from 136 to 318 days after hatching. DAH = days after hatching; $\mathrm{TL}=$ total length; $\mathrm{SL}=$ standard length; $\mathrm{V}=$ volume; $\mathrm{BD}=$ body density; $\mathrm{n}=$ sample size for each of the 14 assessments; Fulton's K = Fulton's condition factor.

\begin{tabular}{|c|c|c|c|c|c|c|c|}
\hline $\begin{array}{l}\text { Age } \\
\text { (DAH) }\end{array}$ & $\mathrm{n}$ & $\begin{array}{l}\text { Weight } \\
\text { (g) }\end{array}$ & $\begin{array}{l}\mathrm{TL} \\
(\mathrm{cm})\end{array}$ & $\begin{array}{l}\text { SL } \\
(\mathrm{cm})\end{array}$ & $\begin{array}{l}\mathrm{V} \\
(\mathrm{mL})\end{array}$ & $\begin{array}{l}\mathrm{BD} \\
\left(\mathrm{g} \mathrm{mL}^{-1}\right)\end{array}$ & $\begin{array}{l}\text { Fulton's K } \\
\left(\mathrm{g} \mathrm{mm}^{-3}\right) 10^{2}\end{array}$ \\
\hline 136 & 15 & 37.69 & 12.96 & 9.32 & 32.91 & 1.17 & 1.73 \\
\hline 150 & 13 & 49.44 & 14.25 & 10.18 & 46.10 & 1.08 & 1.70 \\
\hline 164 & 15 & 65.01 & 15.83 & 11.35 & 62.63 & 1.04 & 1.64 \\
\hline 178 & 15 & 93.00 & 17.53 & 12.68 & 84.57 & 1.11 & 1.73 \\
\hline 192 & 15 & 124.86 & 18.97 & 13.72 & 126.17 & 0.99 & 1.84 \\
\hline 206 & 15 & 184.66 & 21.45 & 15.55 & 183.31 & 1.01 & 1.87 \\
\hline 219 & 15 & 238.71 & 23.37 & 17.20 & 237.26 & 1.01 & 1.87 \\
\hline 234 & 15 & 317.67 & 25.45 & 18.69 & 309.94 & 1.03 & 1.93 \\
\hline 248 & 15 & 408.25 & 27.06 & 20.37 & 395.89 & 1.03 & 2.06 \\
\hline 262 & 15 & 513.93 & 29.22 & 21.94 & 504.69 & 1.02 & 2.06 \\
\hline 276 & 15 & 610.60 & 30.90 & 23.35 & 611.66 & 1.00 & 2.07 \\
\hline 290 & 15 & 689.93 & 32.16 & 24.27 & 688.46 & 1.00 & 2.07 \\
\hline 304 & 15 & 721.33 & 32.11 & 24.15 & 717.26 & 1.01 & 2.18 \\
\hline 318 & 15 & 874.07 & 34.65 & 26.52 & 858.59 & 1.02 & 2.10 \\
\hline Linear coefficient & - & 156.179 & 34.777 & 47.093 & 156.748 & NS & 1.271 \\
\hline Angular coefficient & - & 0.201 & 8.009 & 10.099 & 0.202 & NS & 0.003 \\
\hline$R$ & - & 0.976 & 0.996 & 0.996 & 0.977 & NS & 0.953 \\
\hline
\end{tabular}

change or exhibit any association with age $(\mathrm{P}>0.05)$. The yield of the remainder of the carcass with the head $(\mathrm{nCH})$, the water content and the ash and protein contents of the dry matter showed a negative linear trend $(P<0.05)$. In contrast, the fat content of the dry matter and the yield of the fillet with the skin $(\mathrm{nFS})$ increased linearly and positively $(\mathrm{P}<0.05)$ with age (Table 2).

The BIA variables ( $\mathrm{R}$ and $\mathrm{Xc}$ ) and the related parameters (Z, PA and CI) increased directly and linearly with age (Table 3). Reactance was the least stable. Among the ichthyometric variables, the least stable was volume. After 180 days after hatching, the stability of these variables increased.

In the correlation study using the bromatological data (Table 2), the use of the ichthyometric data (Table 1), as well as the BIA data (Table 3), enabled the determination of the extent to which the independent variables explain the variations observed in the eighteen alternative models tested.

Only the best models for the predicting fat, protein and ash contents (as percentages of the dry matter) based on the ichthyometric and BIA data are shown in Table 4. The best models for predicting the total fat mass and the protein and ash contents (in grams) based on ichthyometric and BIA data are shown in Table 5. In both cases, only the protein component had relatively low coefficients of determination. 
Table 2 - Colossoma macropomum $\times$ Piaractus brachypomus. Data for the yields of carcass and fillet and for the body composition from 136 to 318 days after hatching. $\mathrm{DAH}=$ days after hatching; $\mathrm{nWC}=$ yield of the whole carcass with the head, fillet, and skin; $\mathrm{nCH}=$ yield of the remainder of the carcass with the head; $\mathrm{nFS}=$ yield of the fillet with the skin; ashDM, fatDM, and protDM = ash, fat, and protein contents of the dry matter, respectively; NS = not significant.

\begin{tabular}{llllllll}
\hline $\begin{array}{l}\text { Age } \\
\text { (DAH) }\end{array}$ & $\begin{array}{l}\mathrm{nWC} \\
(\%)\end{array}$ & $\mathrm{nCH}(\%)$ & $\mathrm{nFS}(\%)$ & $\begin{array}{l}\text { Water content } \\
(\%)\end{array}$ & $\begin{array}{l}\text { ashDM } \\
(\%)\end{array}$ & $\begin{array}{l}\text { fatDM } \\
(\%)\end{array}$ & $\begin{array}{l}\text { protDM } \\
(\%)\end{array}$ \\
\hline 136 & 88.77 & 61.90 & 26.88 & 76.37 & 14.61 & 12.58 & 71.12 \\
\hline 150 & 85.28 & 55.22 & 30.06 & 77.54 & 13.99 & 13.89 & 72.85 \\
\hline 164 & 86.64 & 58.33 & 28.31 & 73.37 & 13.89 & 17.77 & 62.04 \\
\hline 178 & 86.07 & 51.39 & 34.67 & 75.35 & 14.38 & 14.67 & 76.64 \\
\hline 192 & 86.51 & 51.70 & 34.81 & 74.25 & 13.80 & 18.38 & 70.65 \\
\hline 206 & 85.53 & 49.41 & 36.11 & 72.40 & 12.88 & 22.57 & 61.99 \\
\hline 219 & 86.40 & 48.40 & 38.00 & 72.77 & 12.14 & 22.81 & 60.45 \\
\hline 234 & 87.59 & 52.86 & 34.73 & 70.40 & 12.24 & 26.61 & 57.23 \\
\hline 248 & 87.25 & 52.01 & 35.24 & 68.87 & 11.27 & 30.44 & 54.13 \\
\hline 262 & 70.15 & 41.44 & 28.72 & 67.31 & 10.71 & 33.53 & 66.57 \\
\hline 276 & 85.94 & 45.47 & 40.47 & 66.19 & 10.84 & 38.48 & 50.41 \\
\hline 290 & 86.52 & 45.91 & 40.61 & 65.44 & 10.68 & 36.87 & 63.09 \\
\hline 304 & 86.67 & 47.55 & 39.12 & 65.83 & 10.73 & 37.77 & 45.81 \\
\hline 318 & 87.88 & 46.29 & 41.09 & 64.22 & 10.61 & 38.20 & 50.73 \\
\hline Linear coefficient & - & 67.630 & 20.709 & 87.483 & 18.094 & 5.605 & 85.122 \\
\hline Angular coefficient & - & -0.075 & 0.026 & -0.074 & -0.025 & 1.319 & -0.976 \\
\hline R & NS & 0.811 & 0.763 & 0.974 & 0.958 & 0.983 & 0.766 \\
\hline
\end{tabular}

Table 3 - Colossoma macropomum $\times$ Piaractus brachypomus. Bioimpedance data from 136 to 318 days after hatching. $\mathrm{DAH}=$ days after hatching; $\mathrm{R}=$ resistance; $\mathrm{Xc}_{\mathrm{C}}=$ reactance; $\mathrm{Z}=$ bioimpedance; $\mathrm{PA}=$ phase angle; $\mathrm{Cl}_{\mathrm{S}}=$ composition index using reactance and the length and distance between the detector electrodes (S)

\begin{tabular}{llllll}
\hline $\begin{array}{l}\text { Age } \\
(\mathrm{DAH})\end{array}$ & $\begin{array}{l}\mathrm{R} \\
(\mathrm{Ohm})\end{array}$ & $\begin{array}{l}\mathrm{XC} \\
(\mathrm{Ohm})\end{array}$ & $\begin{array}{l}\mathrm{Z} \\
(\mathrm{Ohm})\end{array}$ & $\begin{array}{l}\mathrm{PA} \\
\left({ }^{\circ}\right)\end{array}$ & $\begin{array}{l}\mathrm{Cl}_{\mathrm{S}} \\
\left(\mathrm{cm}^{2} \mathbf{O h m}^{-1}\right)\end{array}$ \\
\hline 136 & 151.33 & 38.73 & 156.24 & 14.31 & 0.18 \\
\hline 150 & 139.31 & 35.54 & 143.79 & 14.27 & 0.24 \\
\hline 164 & 167.73 & 49.33 & 174.89 & 16.31 & 0.27 \\
\hline 178 & 162.60 & 60.27 & 173.46 & 20.33 & 0.34 \\
\hline 192 & 148.07 & 47.47 & 155.51 & 17.76 & 0.51 \\
\hline 206 & 161.33 & 60.47 & 172.37 & 20.55 & 0.62 \\
\hline 219 & 163.07 & 61.40 & 174.30 & 20.60 & 0.83 \\
\hline 234 & 154.80 & 67.07 & 168.75 & 23.41 & 0.91 \\
\hline 248 & 168.73 & 79.47 & 186.55 & 25.19 & 0.99 \\
\hline 262 & 176.80 & 80.07 & 194.13 & 24.37 & 1.26 \\
\hline 276 & 168.73 & 77.47 & 185.74 & 24.57 & 1.51 \\
\hline 290 & 179.13 & 85.07 & 198.35 & 25.38 & 1.43 \\
\hline 304 & 154.40 & 66.73 & 168.25 & 23.33 & 1.88 \\
\hline 318 & 174.73 & 81.93 & 193.09 & 25.08 & 1.84 \\
\hline Linear coefficient & 1.346 & 7.634 & 129.249 & 6.832 & -1.337 \\
Angular coeffi- \\
cient & 0.121 & 0.247 & 0.200 & 0.063 & 0.001 \\
R & 0.616 & 0.890 & 0.737 & 0.913 & 0.984 \\
\hline & & & & & \\
\hline
\end{tabular}

The best models for predicting the relative water content (\%), the total water content, the yield of the fillet with the skin (nFS), the yield of the remainder of the carcass with the head $(\mathrm{nCH})$, based on the ichthyometric and BIA variables, showed high correlation coefficients: $\mathrm{R}^{2}$ 0.98, 1.00, 0.66 and 0.74 , respectively.

The best models for predicting the relative fat, protein and ash contents (as percentages of the dry matter), based on the BIA variables only, showed an $\mathrm{R}^{2}$ of $0.94,0.64$ and 0.89 , respectively. The best models for predicting the total fat, protein and ash contents (in grams), based on the BIA variables only, showed an $\mathrm{R}^{2}$ of $0.92,0.93$ and 0.97 , respectively. The best models for predicting the relative water content (\%), the total water content and the yields (carcass and fillet) based on the BIA variables only, showed an $\mathrm{R}^{2}$ of $0.92,0.98$ and 0.65 , respectively.

Data from the approximate analysis of the fat, protein and ash contents, expressed as percentages of the dry matter or in grams in the whole fish, were regressed against the corresponding values predicted using the best models based on the ichthyometric and BIA variables or only the BIA variables. High correlation coefficients were observed in both sets of variables. The average differences between the approximate analysis data and the predicted data were small, except for those for the protein content of the dry matter. 
Table 4 - Colossoma macropomum $\times$ Piaractus brachypomus. Equations (best models) for estimating the percentages of fat, protein, and ash in the dry matter (DM) based on ichthyometric and impedance variables. Age = days after hatching; $\mathrm{R}=$ electrical resistance, $\mathrm{W}=$ weight; $\mathrm{SL}=$ standard length; $\mathrm{PA}=$ phase angle; $\mathrm{Cl}_{\mathrm{TL}}=$ composition index using the total length and the reactance; $\mathrm{n}=$ number of assessments performed throughout the experiment

\begin{tabular}{|c|c|c|c|c|c|}
\hline Component & $n$ & BIA and ichthyometric data & $P$ value & F value & $\mathrm{R}^{2}$ \\
\hline Fat DM\% ${ }^{1}$ & 14 & Age, $\mathrm{R}, \mathrm{Cl}_{\mathrm{TL}}, \mathrm{W}$ and $\mathrm{SL}$ & $<0.0001$ & 71.05 & 0.9780 \\
\hline Protein DM\%² & 14 & Age, $\mathrm{R}, \mathrm{Cl}_{\mathrm{TL}}, \mathrm{W}$ and $\mathrm{SL}$ & $<0.0504$ & 3.68 & 0.6970 \\
\hline Ash DM\% ${ }^{3}$ & 14 & Age, PA, W and SL & $<0.0001$ & 77.78 & 0.9719 \\
\hline
\end{tabular}

${ }^{1} y=-8.422926267-0.216712691$ Age $+0.116915731 R+1.901114939 \mathrm{Cl}_{-}-0.002513132 \mathrm{~W}+2.692125898 \mathrm{SL}$.

$2 y=114.3994883+0.2419623$ Age- $0.2438099 R-5.9064319 C C+0.0318951 \mathrm{~W}-1.3784901 \mathrm{SL}$.

${ }^{3} \mathrm{y}=15.57348218+0.03622345 \mathrm{Age}+0.17683248 \mathrm{PA}+0.00392687 \mathrm{~W}-0.93035346 \mathrm{SL}$.

Table 5 - Colossoma macropomum $\times$ Piaractus brachypomus. Equations (best models) for estimating the contents of fat, protein, ash, and water (in grams) based on ichthyometric and impedance variables. Age = days after hatching; $\mathrm{R}=$ electrical resistance; $\mathrm{W}=$ weight; $\mathrm{SL}=$ standard length; $\mathrm{PA}=$ phase angle; $\mathrm{Cl}_{\mathrm{LT}}=$ composition index using the total length and the reactance; $\mathrm{Cl}_{\mathrm{S}}=$ composition index using the separation between the detector electrodes and the reactance,; $n=$ number of assessments performed throughout the experiment

\begin{tabular}{llllll}
\hline Component & $\mathrm{n}$ & BIA and ichthyometric data & P value & F value & $\mathrm{R}^{2}$ \\
\hline Total fat $^{1}$ & 14 & Age, PA, W and SL & $<0.0001$ & 740.17 & 0.997 \\
Total protein $^{2}$ & 14 & Age, $\mathrm{R}, \mathrm{Cl}$, , W, and SL & $<0.0001$ & 73.19 & 0.979 \\
Total ash $^{3}$ & 14 & Age, PA, W and SL & $<0.0001$ & 2968.13 & 0.999 \\
\hline
\end{tabular}

${ }^{1} \mathrm{y}=34.76580235-0.03550451$ Age-0.05527718PA+0.22293449W-3.66602166SL

${ }^{2} \mathrm{y}=-45.24958532-0.12274079 \mathrm{Age}+0.26813712 \mathrm{R}-53.84934130 \mathrm{CIS}+0.24910634 \mathrm{~W}+3.13248886 \mathrm{SL}$

${ }^{3} \mathrm{y}=0.7286658391+0.0197805130 \mathrm{Age}+0.0784306263 \mathrm{PA}+0.0426013459 \mathrm{~W}-0.5106010683 \mathrm{SL}$.

The correlations between the approximate analysis data and the corresponding predicted values calculated using the best models based on the ichthyometric and BIA variables for the water content, either as the relative water content (\%) or as the total water content $(\mathrm{g})$, had high correlation coefficients: 0.99 and 1.00 , respectively. An identical analysis for the yield of the fillet with the skin $(\mathrm{nFS})$ and yield of the remainder of the carcass with the head $(\mathrm{nCH})$ resulted in lower correlation coefficients: 0.80 and 0.86 , respectively.

The calculation of Mallows' Cp statistic allowed us to verify the adjustment of the sets of independent variables tested when constructing the models based on the ichthyometric and BIA variables or only the BIA variables.

In this study, the inclusion of the BIA variables and parameters in the models resulted in small but distinct increases in the $\mathrm{R}^{2}$ values as compared with the $\mathrm{R}^{2}$ values of the models without the BIA variables.

\section{DISCUSSION}

A study carried out with largemouth bass (Micropterus salmoides), bluegill (Lepomis macrochirus) and redear sunfish (Lepomis microlophus) revealed that room temperature changes of approximately $10{ }^{\circ} \mathrm{C}$ did not significantly alter the $\mathrm{R}$ and Xc readings (Duncan 2008). In bluefish (Pomatomus saltatrix), BIA measurements at 15 and $27^{\circ} \mathrm{C}$ resulted in significant changes of R and Xc (Hartman et al. 2011). Therefore, the
BIA values in the present study were not influenced by the small temperature variations in the environment where the measurements were taken.

The linear increase in Fulton's $\mathrm{K}$ with age indicates that there was an improvement in the condition of the fish over the study period (Table 1). Similarly to the body mass index (BMI), an estimator of the nutritional status of humans (WHO 1995), Fulton's K is used to estimate the nutritional condition or status of fish (Nash et al. 2006).

Although BIA variables were first studied in hypothetical cylindrical bodies (Lukaski 1987), the shape of tambatinga, which must be considered when choosing the insertion points of the electrodes for determining R and Xc, did not reduce the stability of these variables (Table 3 ).

There are no previous studies using the BIA to evaluate the body composition of fish in general or hybrid fish specifically, including tambatinga, in Brazil.

Nevertheless, results similar to those of this study have been published, although they come from studies conducted with fusiform fish. Regression models for channel catfish (Ictalurus punctatus) including total weight, R, Xc and electrode distance (separation) as independent variables explain $71,75.8$ and $65 \%$ of the variation in carcass yield, fat content and relative water content, respectively (Bosworth and Wolters 2001). 
A study conducted with brook trout (Salvelinus fontinalis) revealed strong correlations between BIA variables and energy density $\left(R^{2} 0.94\right)$, fat mass $\left(R^{2} 0.92\right)$, protein mass $\left(R^{2} 0.98\right)$, dry matter $\left(R^{2} 0.98\right)$ and ash content $\left(R^{2} 0.96\right)$. In the model construction, the relationship between the square of the total length and the resistance or the reactance in series was used as an independent variable for most calculations (Cox and Hartman 2005).

Studying Chinook salmon (Oncorhynchus tshawytscha), Margraf et al. (2005) obtained $\mathrm{R}^{2}$ values of $0.90,0.89$ and 0.70 for the relationships between the BIA data and the percentages of fat, protein and ash in the dry matter, respectively; and $\mathrm{R}^{2}$ values of 0.83 and 0.86 for the water content and energy density, respectively. Their models included resistance, reactance and the distance between the anterior and posterior electrodes.

An experiment with yellow perch (Perca flavescens), walleye (Sander vitreus) and lake whitefish (Coregonus clupeaformis) aimed at predicting the energy density and the percentage and mass of lipids using the BIA technique showed good correlations and good models for estimating the dry mass, lipid mass and energy density. That study also revealed differences among the fish: it underestimated the energy density and the percentage of lipids in lipid-rich fish, and overestimated the energy density and the percentage of lipids in low-lipid fish. The different models included the following as independent variables: weight, total length, the resistance and reactance in parallel, and the relationship between the square of the length and the resistance in parallel (Pothoven et al. 2008).

A study carried out with bluegill (Lepomis macrochirus), redear sunfish (Lepomis microlophus), northern logperch (Percina caprodes) and brook trout (Salvelinus fontinalis) using models that included the relationship between the square of the signal electrode distance and the resistance as an independent variable resulted in determination coefficients ranging from 0.71 to 0.99 for the estimation of the body composition variables (total fat, lean mass, total protein, total ash and total body water) using BIA, with small variations among the fish (Duncan, 2008).

There was strong predictive relationship between BIA data and the energy content $\left(R^{2} 0.90\right)$, total body water content $\left(\mathrm{R}^{2} 0.89\right)$ and dry matter $\left(\mathrm{R}^{2} 0.80\right)$ for the rainbow trout (Oncorhynchus mykiss). BIA enabled the detection of differences in these parameters among groups fed different amounts of food, corroborating the accuracy and reliability of this technique for estimating the energy content and body composition of fish. The models included the relationship between the square of the length and the resistance or reactance, in series or in parallel (Bourdages 2011).

The inclusion of BIA variables and parameters in the models in the present study resulted in small increases in the
$\mathrm{R}^{2}$ values. A similar result was reported by Pothoven $e t$ al. (2008), with other fish.

Given the influence of other ichthyometric variables not studied here, on fish yield (Reis Neto et al. 2012; Silva et al. 2009; Leonhardt et al. 2006), we suggest that its relations with the BIA data be further researched.

\section{CONCLUSION}

In the hybrid tambatinga, despite its round shape, bioelectrical impedance analysis (BIA) allows the estimation of the yield of fillet with skin, and body composition (fat, ash and protein contents of the dry matter or the total mass of the fish, as well as the relative water content or the total water content). The best models included both ichthyometric and BIA variables or parameters.

\section{ACKNOWLEDGEMENTS}

We are grateful to the Departamento Nacional de Obras Contra as Secas (Piripiri - Piauí, Brasil) for providing the juvenile tambatinga so that we could conduct this experiment.

\section{REFERENCES}

Association of Official Analytical Chemists - AOAC. 1984. Official methods of analysis of the Association of Official Analytical Chemists, 14th edition. Arlington, VA, $1141 \mathrm{p}$.

Bomfim, M.A.D.; Lanna, E.A.T.; Donzele, J.L.; Abreu, M.L.T.; Ribeiro, F.B.; Quadros, M. 2008. Reduction of crude protein with amino acid supplementation, based on ideal protein concept, in diets for Nile tilapia fingerlings ideal protein concept, in diets for Nile tilapia fingerlings. Revista Brasileira de Zootecnia, 37: 1713-1720.

Bosworth, B.G.; Wolters, W.R. 2001. Evaluation of bioelectric impedance to predict carcass yield, carcass composition, and fillet composition in farm-raised catfish. Journal of World Aquaculture Society, 32:72-78.

Bourdages, C. 2011. Use of bioelectrical impedance analysis (BIA) to predict water and energy content of juvenile rainbow trout (Oncorhynchus mykiss). Master of Science dissertation, Faculty of Science of the University of Ontario Institute of Technology, Oshawa, Ontario, Canada. 141p.

BRASIL. Ministério da Pesca e Aquicultura. 2010. Boletim Estatístico da Pesca e Aquicultura. MBA. Brasília, 129p.

Braulio, V.B.; Furtado, V.C.S.; Silveira, M.G.; Fonseca, M.H.; Oliveira, J.E. 2010. Comparison of body composition methods in overweight and obese Brazilian women. Arquivos Brasileiros de Endocrinologia \& Metabologia, 54: 398-405.

Cox, M.K.; Hartman, K.J. 2005. Nonlethal estimation of proximate composition in fish. Canadian Journal of Fisheries and Aquatic Sciences, 62: 269-275.

Duncan, M.; Craig, S.R.; Lunger, A.N.; Kuhn, D.D.; Salze, G.; McLean, E. 2007. Bioimpedance assessment of body 
composition in cobia Rachycentron canadum (L. 1766). Aquaculture, 271: 432-438.

Duncan, M.B. 2008. The use of BIA for estimating the body composition of various fish species. Master of Science dissertation, Faculty of Virginia Polytechnic Institute and State University, Blacksburg, VA. 74 p.

Ellis, K.J. 2000. Human body composition: in vivo methods. Physiological Reviews, 80: 649-680.

Ellis, K.J. 2001. Selected Body composition methods can be used in field studies. The Journal of Nutrition, 131: 1589S-1595S.

Foster, K.R.; Lukaski, H.C. 1996. Whole-body impedance - what does it measure? The American Journal of Clinical Nutrition, 64: 388S-396S.

Freato, T.A.; Freitas, R.T.F.; Santos, V.B.; Logato, P.V.R.; Viveiros, A.T.M. 2005. Effect of body weight on processing yields of piracanjuba (Brycon orbignyanus Valenciennes, 1849). Ciência e Agrotecnologia, 29: 676-682.

Hartman, K.J.; Phelan, B.A.; Rosendale, J.E. 2011. Temperature effects on bioelectrical impedance analysis (BIA) used to estimate dry weight as a condition proxy in coastal bluefish. Marine and Coastal Fisheries: Dynamics, Management, and Ecosystem Science, 3:307-316.

IBAMA - Instituto Brasileiro do Meio Ambiente e dos Recursos Naturais Renováveis. 2008. Estatística da Pesca 2006 Brasil: Grandes Regióes e Unidades da Federação. IBAMA. Brasília, $174 \mathrm{p}$.

Kyle, U.G.; Bosaeus, I.; De Lorenzo, A.D.; Deurenberg, P.; Elia, M.; Gómez, J.M.; Heitmann, B.L.; Kent-Smith, L.; Melchior, J.C.; Pirlich, M.; Scharfetter, H.; Schols, A.M.W.J.; Pichard, C. 2004a. Bioelectrical impedance analysis-part II: utilization in clinical practice. Clinical Nutrition, 23: 1430-1453.

Kyle, U.G.; Bosaeus, I.; De Lorenzo, A.D.; Deurenberg, P.; Elia, M.; Gómez, J.M.; Heitmann, B.L.; Kent-Smith, L.; Melchior, J.C.; Pirlich, M.; Scharfetter, H.; Schols, A.M.W.J.; Pichard, C. 2004b. Bioelectrical impedance analysis-part I: review of principles and methods. Clinical Nutrition, 23: 1226-243.

Leonhardt, J.H.; Caetano Filho, M.; Frossard, H.; Moreno, A.M. 2006. Morphometrics, fillet yield and fillet composition in Nile tilapia, Oreochromis niloticus, strains thai chitralada, Brazil local and their hybrid. Semina: Ciências Agrárias, 27:125-132.

Lukaski, H.C. 1987. Methods for the assessment of human body composition: traditional and new. American Journal of Clinical Nutrition, 46: 537-556.

Margraf, J.F.; Hartman, K.J.; Cox, M.K. 2005. Non-lethal estimation of energy content of Yukon River Chinook salmon. Final report to Arctic-Yukon-Kuskokwim Sustainable Salmon Initiative. University of Alaska, Fairbanks, Alaska. 27p.
Nash, R.D.M.; Valencia, A.H.; Geffen, A.J. 2006. The origin of Fulton's condition factor-setting the record straight. Fisheries, 31: 236-238.

Pinto, E.; Oliveira, A.R.; Alencastre, H.; Lopes, C. 2005. Body composition assessment in children with non invasive methods. Arquivos de Medicina, 19: 47-54.

Pothoven, S.A.; Ludsin, S.A.; Höök, T.O.; Fanslow, D.L.; Mason, D.M.; Collingsworth, P.D.; Van Tassell, J.J. 2008. Reliability of bioelectrical impedance analysis for estimating whole-fish energy density and percent lipids. Transactions of the American Fisheries Society, 137: 1519-1529.

Reis Neto, R.V.; Freitas, R.T.F.; Serafini, M.A.; Costa, A.C.; Freato, T.A.; Rosa, P.V.; Allaman, I.B. 2012. Interrelationships between morphometric variables and rounded fish body yields evaluated by path analysis. Revista Brasileira de Zootecnia, 41:1576-1582.

Statistical Analysis System - SAS. 2004. SAS Institute Inc., Cary, NC, USA.

Silva, D.J.; Queiróz, A.C. 2002. Food analysis: chemical and biological methods. Viçosa - MG: Ed UFV; Viçosa. 235p.

Silva, F.V.; Sarmento, N.L.A.F.; Vieira, J.S.; Tessitore, A.J.A.; Oliveira, L.L.S.; Saraiva, E.P. 2009. Características morfométricas, rendimentos de carcaça, filé, vísceras e resíduos em tilápias-donilo em diferentes faixas de peso. Revista Brasileira de Zootecnia, 38:1407-1412.

Soares, M.G.M.; Costa, E.L.; Siqueira-Sousa, F.K.; Anjos, H.D.B.; Yamamoto, K.C.; Freitas, C.E.C. 2008. Peixes de lagos do médio Rio Solimóes. Manaus: Ed Instituto I-piatam; Manaus. 176p.

Teixeira, E.A.; Crepaldi, D.V.; Faria, P.M.C.; Ribeiro, L.P.; Melo, D.C.; Euler, A.C.C.; Sousa, A.B.; Saliba, E.O.S. 2006. Methods for fish amino acids requirements determination. Revista Brasileira de Reprodução Animal, 30: 126-133.

Valliant, M.W.; Tidwell, D.K. 2007. Validation of bioelectrical impedance against dual-energy X-ray absorptiometry in adult, African American females. Journal of the American Dietetic Association, 107:A29.

Vidal, L.V.O.; Albinati, R.C.B.; Albinati, A.C.L.; Lira, A.D.; Almeida, T.R.; Santos, G.B.S. 2008. Eugenol as an anaesthetic for Nile tilapia. Pesquisa Agropecuária Brasileira, 43: 1069-1074.

Willis, J.; Hobday, A.J. 2008. Application of bioelectrical impedance analysis as a method for estimating composition and metabolic condition of southern bluefin tuna (Thunnus maccoyii) during conventional tagging. Fisheries Research, 93: 64-71.

WHO.1995. Physical status: the use and interpretation of anthropometry. Technical Report Series, n.854. World Health Organization, Geneva. 47p.

Recebido em 18/03/2013

Aceito em 01/07/2013 
